\title{
Serum Bicarbonate Decreased
}

National Cancer Institute

\section{Source}

National Cancer Institute. Serum Bicarbonate Decreased. NCI Thesaurus. Code C78181.

A laboratory test result which indicates decreased levels of bicarbonate in the serum. 